\title{
"Terrace Mound Farm:" The 1892 Diary of John W. Slemmons
}

\author{
edited by H. ROGER GRANT
}

The diary entries of John W. Slemmons have historical significance. Even though this Iowa farmer failed to reflect at length on his daily happenings-the limited space in his pocket notebook precluded this-his writings, nonetheless, graphically reveal the activities and interests of the unknown and unheralded type of man who fed and clothed the nation during the 1890s. This is a rare glimpse. Indeed until recently, the lives of anonymous Americans, like Slemmons, have received slight attention by the historical profession. Not only was "common person" history unfashionable, but the historical depositories across the country contained few manuscripts from farmers, although they bulged with the papers of politicians, generals, and other allegedly important people. ${ }^{1}$

The writings of John Slemmons portray a representative Iowa agrarian. He is intimately involved in the commercial agricultural pursuits of the day. ${ }^{2}$ The Slemmons "Terrace Mound" farm

${ }^{1}$ One valuable published Iowa farm diary is H. Roger Grant and L. Edward Purcell, eds., Years of Struggle: The Farm Diary of Elmer G. Powers, 19311936 (Ames: Iowa State University Press, 1976).

${ }^{2}$ By the closing years of the nineteenth century diversity characterized Iowa agriculture. Stock raising and dairying had largely replaced the soil-exhausting grain economy of the frontier era. This factor coupled to the immense productivity of the land allowed tillers to enjoy relative prosperity at a time when fel- 


\section{Terrace Mound Farm}

of 160 acres supports prized shorthorn cattle, Poland China swine, and Percheron horses. There are also herds of dairy cows and sheep. Slemmons furthermore enters into a myriad of common farm activities that range from trips to the market town with produce to livestock breeding. And, too, he participates in an interrelated and interdependent community of fellow farmers. ${ }^{3}$

The author's personal traits likewise fit the typical Iowa plowman of the period. Slemmons is deeply religious. His attendance at a nearby church is both regular and frequent. He seems gregarious; certainly he "neighbors" with great regularity. Slemmons votes the Republican ticket and he takes an active interest in community affairs. Even his pattern of entertainment is characteristic of his peers: family and neighborhood dinners and socials, trips to state and local fairs, and occasional visits to a passing circus or lecture. And his deep interests in what can be labeled "scientific" agriculture are evident, whether membership in the American Poland China Association or the reading and selling of the sophisticated livestock periodical, The Breeder's Gazette.

The Slemmons diary, too, reflects the monotony of farm life. The fieldwork, caring for livestock, related chores seem unending. The document also tells of struggles, often weather-related. The awful conditions of area roadways during the spring thaw, for instance, attest to the problems farmers encountered before the eventual triumph of the "good-roads" movement in the 1920 s.

Diary-keeper John W. Slemmons was born in the central Ohio village of Hanover on Christmas day 1841. When still a child his family moved to Cadiz, seat of Harrison County,

low agrarians on the Great Plains and in the South experienced the crippling effects of rock-bottom prices for their single cash crops of wheat and cotton.

${ }^{3}$ For an overview of Hawkeye state farming, see Earle D. Ross, Iowa Agriculture: An Historical Survey (Iowa City: The State Historical Society of Iowa, 1951), especially pp. 71-91. Also of value are Allan G. Bogue, From Prairie to Cormbelt: Farming on the Illinois and Iowa Prairies in the Nineteenth Century (Chicago: University of Chicago Press, 1963), and James Whitaker, Feedlot Empire: Beef Cattle Feeding in Illinois and Iowa, 1840-1900 (Ames: Iowa State University Press, 1975). 


\section{The Annals of Iowa}

Ohio, a community approximately seventy miles to the northeast. J. W.'s father, Matthew Garvin Slemmons, practiced blacksmithing, a trade his son learned prior to moving to Iowa at the end of the Civil War. Before leaving the Buckeye state, J. W. married Agnes Kerr, the daughter of a Presbyterian minister. She was a Cadiz native, born there on December 27, 1843. ${ }^{4}$

The Slemmonses selected rolling prairie in Scott Township, Johnson County, six miles southeast of Iowa City, the former state capital. By the time of the diary they were parents of five living children: Edgar Matthew (1866), Margaret (1869), Anna (1872), Eliza (1874), and Stair (1877). A daughter, Grace (1886), had died in infancy. The "Terrace Mound" enterprise provided the growing family with a comfortable life style. According to J. W.'s accounting for 1892, his gross income amounted to $\$ 2,169.19$, and his net totaled $\$ 328.24$, well above the national farm average.

The saga of John W. Slemmons ended suddenly and tragically. He died on October 16, 1901, the result of a farm accident. Reported the Iowa City Weekly Republican:

Slemmons was repairing a windmill about 2 o'clock, working on a tower about fifty feet in the air. In some way he lost his footing, falling headlong to the earth below, and was killed instantly. No one was around at the time of the accident. Mrs. Slemmons was working in the house and looked out of the window just in time to see her husband falling. The tower is but a short distance from the house and she ran to his assistance immediately, but found him dead. He was badly bruised and cut about the head and face, and his right arm broken in three places. $^{5}$

The Slemmons farm diary is in the possession of a grandson, Charles O. Slemmons, a resident of Akron, Ohio, and is repro-

${ }^{4}$ Charles O. Slemmons of Akron, Ohio, and Jean Slemmons Spencer of Iowa City, Iowa provided biographical information, much of which came from family Bibles. The 1870 and 1880 manuscript censuses for Scott Township, Johnson County, Iowa, likewise proved useful as did the obituary of Matthew Garvin Slemmons in the Iowa City Citizen, August 22, 1906.

${ }^{5}$ Iowa City Weekly Republican, October 23, 1901. 


\section{Terrace Mound Farm}

duced with his encouragement and permission. ${ }^{6}$ The following edited version represents about a tenth of the word volume for 1892. Yet the passages selected are the most valuable in revealing the life of the writer and his world. Spelling errors have generally been corrected and punctuation altered to permit smoother reading. Notes provide clarification of various persons, events, and terms.

Saturday, January 2, 1892

Went to town ${ }^{7}$ today with the butter.

Sunday, January 3, 1892

Was at Sabbath School. Just a fair congregation at Scott. ${ }^{8}$ Rev. Furniss preached a new year sermon from Cor. 7 and 31 . A. splendid sermon which we all could apply.

Monday, January 4, 1892

Went to Iowa City and got the team shod at Kettlewells. ${ }^{9}$ Attended the Agricultural Meeting.

Tuesday, January 5, 1892

Went to town this morning. Went after to Coralville and got a load of hog feed, got 4 boards for feed trough. ${ }^{10}$

Thursday, January 7, 1892

Was home all day helping with chores. Got in some straw for bedding and put some beets in the barn. Went to prayer meeting tonight.

Friday, January 8, 1892

Was home today doing chores. Edgar ${ }^{11}$ went to town for coal

${ }^{6}$ My colleague, Daniel Nelson, a neighbor of the present owner of the diary, brought the Slemmons document to my attention.

${ }^{7}$ The town is Iowa City, population 7,016, six miles to the northwest.

${ }^{8}$ The Scott Church, two miles east of the Slemmons farm, is a Presbyterian congregation; the Reverend Mr. Leo Furniss is minister.

${ }^{9}$ Kettlewell \& Sons, located on Washington Street in Iowa City, operated a blacksmith shop.

${ }^{10}$ Slemmons patronizes a water mill on the Iowa River in Coralville, a village immediately northwest of Iowa City.

${ }^{11}$ Matthew Edgar Slemmons, born September 9, 1866, is the oldest of the 


\section{The Annals of Iowa}

and to get a shoe put on the mare. Coal was scarce. Got 2700 lbs. at Mr. Housers at $\$ 3.50$ per ton. ${ }^{12}$ It was a cold northwest wind today. Broke the sucker rod in pump today.

Sunday, January 10, 1892

Was too late for the opening of Sabbath School and Edgar did not go to church as the pump was froze and he had to thaw it before he could water the cattle. Mr. Furniss preached from Ecclesiastes 12 chapter 13 and 14 ver. Margaret and Frank ${ }^{13}$ stopped for dinner.

Monday, January 11, 1892

At home today doing chores. Got in straw and fodder and hauled out manure. Jay Denton ${ }^{14}$ was here wanting to buy cattle. Offer $2 \frac{1}{2}$ cts. for old cow that is fat.

\section{Tuesday, January 12, 1892}

At home all day. Margaret and Frank were over and we butchered two sow pigs. Charley Gibson ${ }^{15}$ stopped here and looked at the hogs. It was quite cold early in the morning, 14 below zero.

\section{Thursday, January 14, 1892}

Went to help Joshua Ady ${ }^{16}$ haul ice. Brought a load of ice home this eve from Ady's pond. It's about 12 or 13 in. thick. Saturday, January 16, 1892

Went to town today. Took the turkeys in and sold them to LeFevre's $\mathrm{s}^{17}$ at $9 \frac{1}{2} \mathrm{cts}$. per lb. Had $172 \mathrm{lbs}$.

\section{Tuesday, January 19, 1892}

Went to [Iowa] City after did some chores to go to Cedar

children. Married in 1905, Edgar remained on the family farm until the 1920s when he left to launch what became an unsuccessful automobile agency in Iowa City. Later he returned to Scott Township.

${ }^{12} \mathrm{D}$. L. Houser is an Iowa City coal dealer.

${ }^{13}$ Margaret and Frank Danner live on a nearby farm. Margaret, born on August 13, 1869, is the eldest Slemmons daughter. She married Danner on September 12, 1890.

${ }^{14}$ Jay Denton is probably an area farmer.

${ }^{15}$ Charley Gibson farms one mile northwest of the Slemmons homestead.

${ }^{16}$ The Ady farm is located two miles northwest of the Slemmons place, on the "Lower Muscatine" road to Iowa City.

${ }^{17}$ The John Le Fevre grocery is situated on South Dubuque Street in Iowa City. 
Rapids to attend the American Poland China Association. Left the city at 11:30 fare $\$ 1$.

Wednesday, January 20, 1892

Got up at 7. Ate breakfast at Clifton House, Cedar Rapids. Association held session till noon in the dining room of hotel. After dinner got fare to Iowa City and paid hotel bill and left at half past 3 to go home for supper.

Friday, January 22, 1892

Went down to Father's in the morning. Jay Denton came down and I sold him two cows for 3 and $2 \frac{1}{2}$ cts. per lb. respectively.

Tuesday, January 26, 1892

Was butchering today. Killed three hogs at home in forenoon and went down in afternoon and killed two hogs at Father's. Frank and Margaret were over and helped me butcher and brought over a load of corn.

Wednesday, January 27, 1892

I stayed home today and done chores. Edgar went to town with $1 / 2$ hog and brought a load of coal for the Scott Church from Housers. Party up at the Parsonage. Took some live chicken and fruit.

Saturday, January 30, 1892

Went to town this morning and stopped to see Father. He was not so well and wanted me to send the doctor out. ${ }^{18}$ Delivered the butter and $\mathrm{Ma}$ and I went down to Mrs. Anderson's ${ }^{19}$ for dinner party.

Wednesday, February 3, 1892

We ground couple lbs. corn this morning. Went over to Ed Whitacre for dinner. Mr. and Mrs. Thompson, Mr. and Mrs. Taylor, Mr. and Mrs. Bothel, and Rev. Mr. Furniss was there. ${ }^{20}$ Had a splendid dinner. Roads quite muddy this evening.

${ }^{18}$ While the author's father, Matthew Garvin Slemmons, experienced poor health during 1892, he lived until August 22, 1906. At the time of his death, he was eighty-seven years, six months, and eleven days.

${ }^{19}$ Ida Anderson, the author's half-sister, and her husband, Elmer, live several miles to the east.

${ }^{20}$ The Whitacres, close friends of the Slemmonses, live several miles to the east. The Thompsons, Taylors, and Bothels are also neighbors and friends. 


\section{The Annals of Iowa}

\section{Thursday, February 4, 1892}

Found colt chilling in the barn this morning. Put blankets on him and sent for Dr. Edwards. ${ }^{21}$

Saturday, February 6, 1892

Was grinding corn today after we got stables cleaned up. $\mathrm{S}$. H. Thompson was over to see the grinder work. ${ }^{22}$ Monday, February 8, 1892

At home today till after chore time. Went up to Bradley to see if we could cut ice and stopped at Ezra Delwiler to see his sheep. ${ }^{23}$

\section{Wednesday, February 10, 1892}

We cut and hauled ice today. P. C. Ady's hand hauled three loads. Frank Danner hauled 3 loads. Stair ${ }^{24}$ and Edgar hauled 2 loads apiece.

Friday, February 12, 1892

Went to Bradley's pond this morning to haul ice for Grandpa. ${ }^{25}$ Brought 2 loads with each team. Stair did the chores while Edgar and I hauled ice.

Saturday, February 13, 1892

Went to town today. Took wagon. Delivered butter. Had horses shod 175 ct. worth.

Sunday, February 14, 1892

Went to Sabbath School. Mr. Furniss preached from I Peter, I Ch. and 3 and 4 verses. Small congregation out. Spoke of a collection for the starving Russians. ${ }^{26}$

Thursday, February 18, 1892

Was doing chores today. Put sawdust on the ice. Boys

${ }^{21} \mathrm{~F} . \mathrm{H}$. P. Edwards is an Iowa City veterinarian.

${ }^{22} \mathrm{~S}$. H. Thompson, a fellow Scott Township agrarian, is a well-known breeder of "Short-Horn Cattle of extra individual merit."

${ }^{23}$ Neighbor H. A. Bradley owns a pond that supplies local residents with ice. The Delwiler place is a mile southeast of the Slemmons farm.

${ }^{24}$ Stair Kerr Slemmons, the second son, was born September 14, 1877, on the family farm and remained there until his marriage in 1904.

25 "Grandpa" is the author's father.

${ }^{26}$ European Russia suffered from weather-related crop failures between 1891 and 1893. Especially hard hit were the grain-growing regions along the Volga River. 


\section{Terrace Mound Farm}

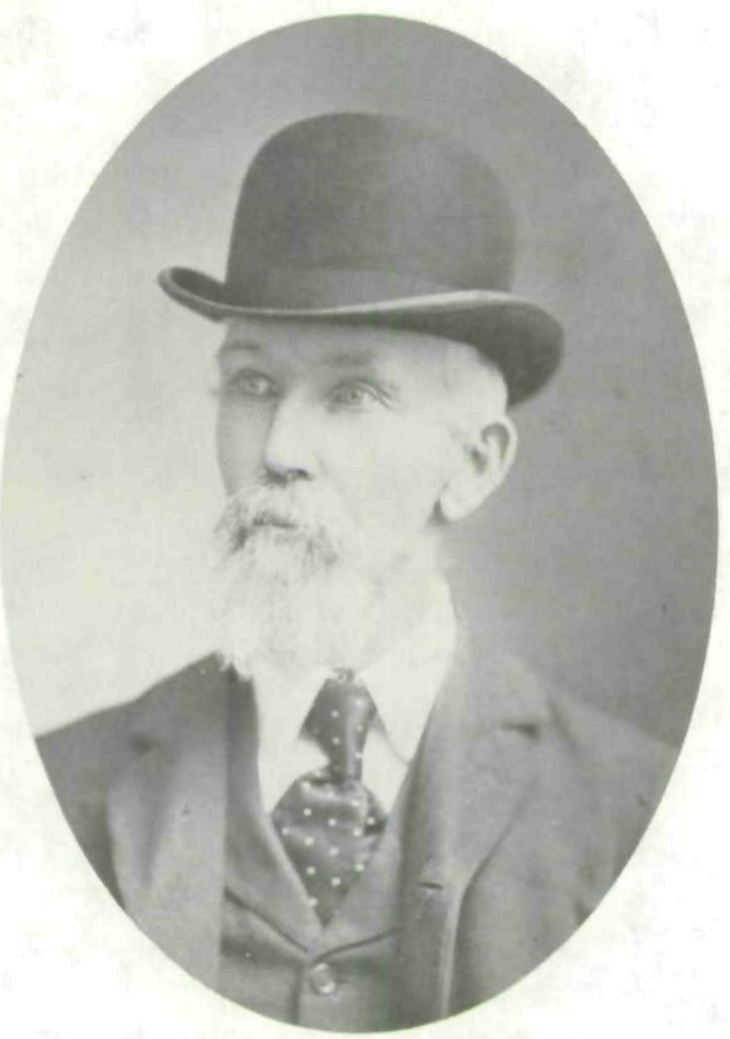

John W. Slemmons, circa 1898.

brought load of beets down from the cellar and put in the barn to feed. Prospect for storm.

Sunday, February 21, 1892

Went to Sunday School in the wagon and was there in time. Mr. Furniss preached a splendid sermon from the text "What is Your Life?" Quite a good congregation out. Got a collection for Bible Society for $\$ 8$.

Tuesday, February 23, 1892

Commenced to smoke the meat. The boys hauled some manure and did the chores. Joshua Ady was up to see the pigs today. 


\section{The Annals of Iowa}

Wednesday, February 24, 1892

Woke this morning and found it raining and it rained all forenoon. I stayed in the house. The boys did chores. They cut willow trees for fire wood this afternoon.

Thursday, February 25, 1892

Went to dinner on invitation to Wm. Meardons, ${ }^{27}$ had a pleasant time. Bright sunshine today, the first for a week.

Friday, February 26, 1892

The roads are fearfully muddy. The frost nearly out.

Saturday, February 27, 1892

Went to town with butter today. Roads very bad and getting worse. Paid Father's tax $\$ 32.77$ and also half my own $\$ 24.32$. Got sack flour.

Sunday, February 28, 1892

Got up this morning and found it drizzling rain and snow. Went to Sunday School on horseback. Only a few out.

Tuesday, March 1, 1892

Doing chores today. Took meat out of smokehouse and packed in barrel.

\section{Sunday, March 6, 1892}

The ground was froze a little this morning so you could walk on the mud. Went to Church and Sabbath School.

Monday, March 7, 1892

We ground a load of corn this morning and mixed it with oats. In the afternoon I went to the School Election.

Thursday, March 10, 1892

Was grinding corn today, had load and $1 / 2$ ground. Went down to see Father tonight. He thinks he is better. Sister Lizzy Welch ${ }^{28}$ wants me to take her in for the early train in the morning. Have to get up at five o'clock.

Friday, March 11, 1892

Got up at a little of four to go to the train. Roads were so rough I did not know how I would get there. Took Sister Lizzy

${ }^{27}$ The William Meardons farm is one and one-half miles east of the Slemmons homestead.

${ }^{28}$ Lizzy (Elizabeth) Welch, the author's sister, lives in Oskaloosa, Iowa. 
to train to go home. Harry was grinding seed today and we got some hay.

Saturday, March 12, 1892

Went to town. Took a load of wood and butter and hams that we smoked. Got a bbl salt and groceries with other things. Sold our hogs for $\$ 4.40$ per hundred.

Monday, March 14, 1892

This day fair and we got ready and took the hogs to town. Frank Danner helped me. They average a little over 200 [pounds]. There was thirty-two of them. Got $\$ 282$ for the lot.

Tuesday, March 15, 1892

At home today. Boys hauled wood from the other place. ${ }^{29}$ Ground a few oats. Turned our sows out to separate them.

Saturday, March 19, 1892

Went to town today with butter. Buggy broke down on college hill. Left it at Corletts $^{30}$ to get repaired. Got one to bring home.

Sunday, March 20, 1892

Got to Sunday School in time. Found a goodly number. There was revivals after Sunday School. Good sized congregation.

Monday, March 21, 1892

Cold and stormy, snow and rain. Went to town with the old buggy to be repaired. Propose to put new spindles for $\$ 9$.

Tuesday, March 22, 1892

Jas. Hedges ${ }^{31}$ brought up sow and bred her to Prince Darkness. Star Diamond $3 d$. had 8 piglets and they were all nice ones too.

Saturday, March 26, 1892

It rained more or less all day and the roads must be fearful. I stayed in the house and the boys did the chores. Wind is in the Northeast. Was not anyone on the road to town today. Still a raining tonight. Did not get the butter in yet.

${ }^{29}$ "The other place" is an 80 -acre parcel north and east of the original Slemmons farm.

${ }^{30}$ The Corlette \& Sons Livery is located at 114 Washington in Iowa City.

${ }^{31}$ The James P. Hedges farm is two miles northwest of the Slemmons place. 


\section{The Annals of Iowa}

Sunday, March 27, 1892

Today was bright but the mud was fearful on the road. Was in time for Sunday School.

Monday, March 28, 1892

Took the butter to town today. Had a nice litter of pigs from Ruby, 7 in number and 6 males. Roads were very bad.

Wednesday, March 30, 1892

Did the chores this forenoon. Frank Danner and Margaret came over and was here for dinner. The congregational meeting came off and the old board of trustees was elected at the Church.

Friday, April 1, 1892

Went up to Church to help fix fence and $\mathrm{Mr}$. Bothel ${ }^{32}$ did not come so I came home. It rained this forenoon and blew very hard all afternoon and night.

Saturday, April 2, 1892

Fair day. Sun shone and the mud fast drying up. Stair, Ma and I went to town. Ma got new teeth today. I paid price for teeth $\$ 15$. Sent $\$ 6$ to Gazette for 4 subscriptions. ${ }^{33}$

Monday, April 4, 1892

Day was very windy and some rain in the morning. I was over to Ed Greevers. ${ }^{34}$

Tuesday, April 5, 1892

Was shearing lambs today.

Wednesday, April 6, 1892

Went down to Father's at noon to witness the marriage of Harry Dysart and Sister Martha Janette. ${ }^{35}$ They were married in East room on the south side by Rev. Leo Furniss.

Monday, April 11, 1892

Ground feed this morning and got the plows fixed up and

${ }^{32} \mathrm{~J}$. N. Bothel operates a farm approximately two and one-half miles to the southeast.

${ }^{33}$ The Breeder's Gazette, printed in Chicago by the Sanders Publishing Company, employed scores of subscription agents throughout the Midwest. The annual rate was $\$ 2.00$ with the representative receiving a fifty cent commission.

${ }^{34} \mathrm{Ed}$ Greever is a neighbor and brother-in-law.

${ }^{35}$ Martha Janette Greever is a half-sister. She and the author have the same father. 


\section{Terrace Mound Farm}

went out before dinner and sowed some oats. Had both plows out in afternoon. After I got done sowing I went up and watered the cattle. Agie Hogue ${ }^{36}$ came up this evening and stayed all night.

\section{Wednesday, April 13, 1892}

This was a very stormy day. The wind blew in the morning and it began to snow in the morning and blew from the east and the ground soon became covered with snow. It is still raining and snowing tonight. We shorn sheep this afternoon.

Thursday, April 14, 1892

It faired up today after snowing in the forenoon. We shorn sheep today. Still have eleven to shear.

Friday, April 15, 1892

This was a fair day. We shorn sheep in the forenoon and Edgar hauled out manure. We finished sowing oats this afternoon and sowed some grass (clover and timothy). Stair did the harrowing.

Saturday, April 16, 1892

Finished putting in oats and sowing grass seed. Took the butter to town today.

Monday, April 18, 1892

Ground feed in the forenoon and Harry Dysart came up in the afternoon and ground a load. Edgar took Mr. Thompson and I to the city to go on the train to Chicago to attend cattle sales of Sanger and Sons. ${ }^{37}$

Tuesday, April 19, 1892

Arrived in Chicago over the C.R.I. \& P. ${ }^{38}$ Fare was $\$ 6.65$. Got breakfast at the Transit-house. Saw the cattle in forenoon and attended sale in the afternoon.

Wednesday, April 20, 1892

Got a room with two beds. Got breakfast and visited the

${ }^{36}$ Agie Hogue is the author's sister.

${ }^{37}$ Slemmons likely learned of the sale through the Breeder's Gazette. C. M. Sanger \& Sons of Waukesha, Wisconsin advertised in the April 13, 1892 issue: "Extra Good Individual Short-Horns . . . Dexter Park, Chicago."

${ }^{38}$ The C.R.I. \& P. is the Chicago, Rock Island \& Pacific Railroad or better known as the Rock Island. This powerful Granger road operates its mainline from Chicago to Omaha via Iowa City and Des Moines. 
Stockyards. Attended sale in the afternoon. After supper went to the Rock Island depot and started for home.

Thursday, April 21, 1892

Rode all night on train and came to Iowa City at 8 in morning. Got the mail and S. H. Thompson and I walked out from town. Got home in time for dinner. Shorn some sheep this afternoon.

Friday, April 22, 1892

Was at the Chores today. Boys were cleaning out barn and doing chores. Stair plowed in afternoon. We got the sheep all shorn and the wool put away.

Tuesday, April 26, 1892

Went to town today. Got some hog fence boards and lath and new plow shear at Carson's. ${ }^{39}$

Wednesday, April 27, 1892

Was home all day. Repaired the fence around the house and the road gate and inside gate. Was quite showery in the morning and more or less all forenoon. Cut up and planted a bushel of Early Ohio potatoes this evening after we got a fence made in the hog pens.

Thursday, April 28, 1892

We hauled some manure and ground a load of corn. Harry Dysart was up and shelled and ground a load of corn for Father. Stair was plowing for corn. Went to prayer meeting in the evening.

\section{Saturday, April 30, 1892}

Was home today. Worked on the road a while in the forenoon and the rain drove us in about half past ten. Rained quite hard all afternoon. The boys cleaned out the cellar.

Monday, May 2, 1892

It still rained some today and we repaired fence and built a pen to put Prince Darkness in. The gray mare Queen had a mare colt today.

Tuesday, May 3, 1892

Tore up the sheep pasture fence today and hauled it up to the barn.

${ }^{39} \mathrm{~T}$. C. Carson \& Sons conduct an "Agricultural Implements and Seeds" business on Washington Street in Iowa City. 
Wednesday, May 4, 1892

We rebuilt the sheep pasture fence today and found two young calves up at the upper place this evening. It rained quite brisk tonight and spoiled the plowing for tomorrow.

Friday, May 6, 1892

Worked in the field today. Plowed some and raked up some hedge brush. Harry Dysart brought up a load of corn and ground it.

Saturday, May 7, 1892

Went to town today with the butter. In the afternoon Stair plowed for corn.

Tuesday, May 10, 1892

This has been a wet day and I took the mare Laura 3 years old down to Mr. Secrest ${ }^{40}$ and bred her to the new black horse.

Monday, May 16, 1892

This has been a fair day. Ma and I made some garden. Stair was plowing on the Starret place. ${ }^{41}$ Edgar went over to Frank Danners and brought his planter over. We expect to plant corn in the morning.

Tuesday, May 17, 1892

The day was fair except the showers in the evening and I planted corn all day until it rained in the evening.

Friday, May 20, 1892

We plowed and planted corn today.

Saturday, May 21, 1892

I finished planting the first piece of corn this morning and took the planter home. Frank was plowing and Margaret baking. Father walked up today and was here when I came home. Stayed till after dinner and went home as I took the butter to town. Butter was cheap.

Monday, May 23, 1892

Stair finished plowing for corn today. I planted corn and squashes. Jas P. Hedges was here and paid me for breeding a sow and for the Breeder's Gazette. We got a load of hay at Father's this evening.

${ }^{40} \mathrm{~J}$. Secrest operates a sizable farm three miles east of the Slemmons place.

${ }^{41}$ Occasionally the Slemmons family calls the "other place" or "upper place" the "Starret place" after a previous owner of this eighty-acre parcel. 


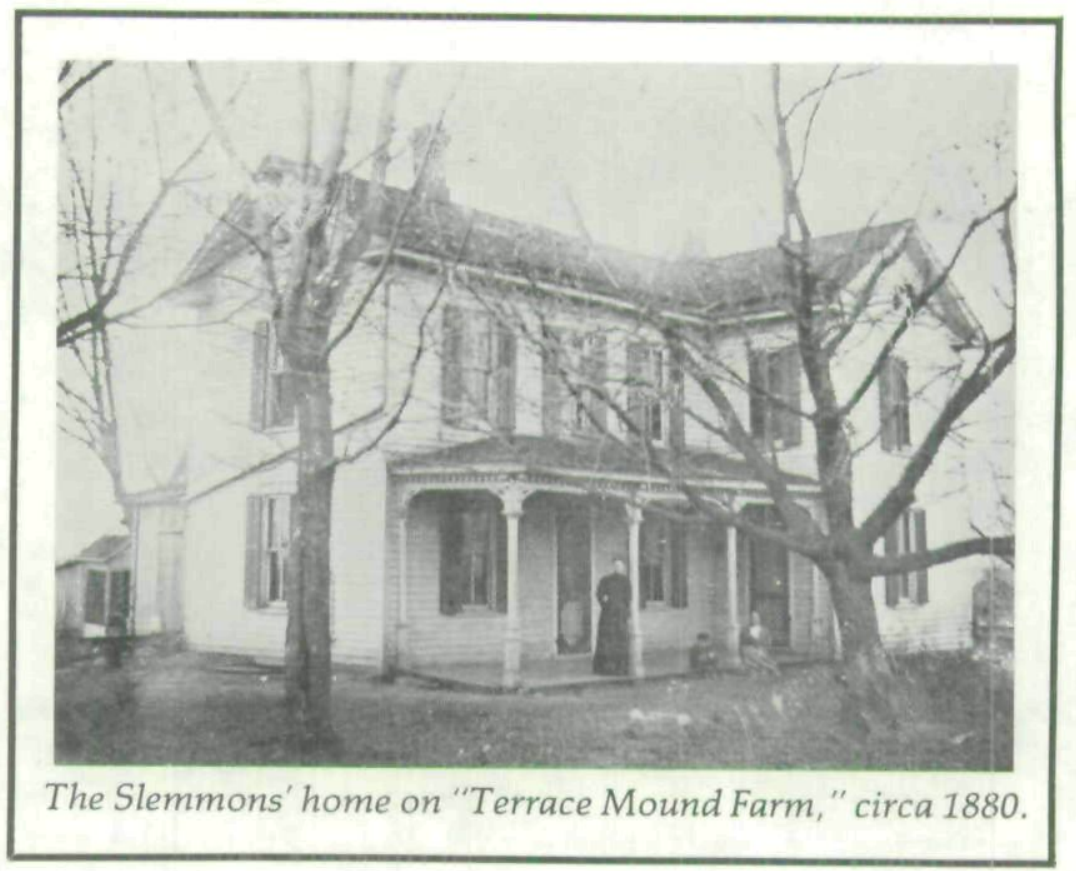

Tuesday, May 24, 1892

I awoke this morning and found it raining. I went to planting corn on the Starret place. It drizzled some through the day. Edgar plowed in the corn. We first planted and Stair harrowed ahead of my planting today. Where it is drained, the ground is in good shape.

Wednesday, May 25, 1892

I finished planting corn today and took the planter home about 3 o'clock. Edgar was plowing with cultivator. Stair was harrowing.

Friday, May 27, 1892

Edgar and I sacked the wool this morning and I took it to town this afternoon. Left it at BCR \& N Depot. ${ }^{42}$ Brought home a load of posts.

Monday, May 30, 1892

This has been a wet day and there was no field work done

${ }^{42}$ The B.C.R. \& N. or Burlington, Cedar Rapids, \& Northern Railroad served West Liberty, Iowa City, and the communities of its corporate name. In 1902 the Rock Island fused the B.C.R. \& N. into its corporate structure. 


\section{Terrace Mound Farm}

today. We split some wood this afternoon. Boys hauled out the manure from the barn.

Thursday, June 2, 1892

This day I went to town. It was cloudy but did not rain much. I got barbed wire for bull pasture and post-hole digger. Got three pairs of rubber boots for the boys.

Friday, June 3, 1892

I went over and saw Frank Danner this morning and bred one of his young mares to Jay. We killed a calf after dinner. Cut the meat up.

Saturday, June 4, 1892

Edgar and I went to town today to get a load of lumber and some oil meal and I to take the butter. We sold Mike Paulus ${ }^{43}$ $10^{1 / 2} \mathrm{lbs}$. of veal at 7 cents per $\mathrm{lb}$. and Mr. S. H. Thompson took 33 lbs. at 7 cents.

Monday, June 6, 1892

Mother ${ }^{44}$ Anna and I went to town today in the buggy. Took calf skin in and went to see furniture, carpet, and etc. Bought carpet at Hornes. ${ }^{45}$ Selected wall paper and engaged men to put it on.

Tuesday, June 7, 1892

Boys planted potatoes on Starret place today. The painters and paper hanger was here today. Papered and painted dining room and varnished parlor.

Wednesday, June 8, 1892

Got done planting beets and put up house for the bull. Boys gathered up stone for foundation. I laid up floor on it. We went to town tonight.

Thursday, June 9, 1892

Worked at Bull house today and Stair was harrowing corn on upper place. Shook carpet and done chores. Isaac $\mathrm{Cox}^{46}$ bred a mare for his hired man to Jay.

${ }^{43}$ A neighbor, Mike Paulus, lives immediately southeast of the Slemmonses.

${ }^{44}$ "Mother" is the author's wife, Agnes Kerr Slemmons. Previous references to "Ma" are also to her.

${ }^{45}$ The J. W. S. Horne Company operates a dry goods and millinery business at 112 South Clinton in Iowa City.

${ }^{46}$ Isaac T. Cox farms two miles east of Slemmons. 


\section{The Annals of Iowa}

Saturday, June 11, 1892

Went to town after taking the calves away to upper pasture. Drove the mare and let sorrel colt go along. Bred her to Atco. Wednesday, June 15, 1892

I took the cows out on the road after milking in the morning. Saw S. H. Thompson. Tore down a piece of fence in the grove and built it over, after which we marked two litters of pigs we had weaned. Ma cleaned out coal house and cellar and cave. Friday, June 17, 1892

I took the butter to town in afternoon. Edgar mowed the graveyard. It rained while I was in town. I got flour at Welches ${ }^{47}$ for $\$ 2.50$ per hundred.

Tuesday, June 21, 1892

Tried to rain this morning but the boys did not stop their corn plowing. I fixed the bull pen and white-washed the kitchen. Boys got done the corn on this place and will go to the other lot in the morning.

Friday, June 24, 1892

Rained last night. We put up hay, barn door and cut weeds and trimmed hedge. Ada Bothel came and got cream for social and lamps also. We had a good time at night at Bothels. Had big crowd.

Monday, June 27, 1892

It was quite cool this day, so much we had to work with our coats on. We shelled a load of corn and ground some oats in the morning before the boys went to plow corn.

Thursday, June 30, 1892

Boys finished working corn. Edgar cut grass this afternoon for the first. I got hayloader fixed up for both wagons today. Friday, July 1, 1892

We put hay in the afternoon. It was pretty green.

Wednesday, July 6, 1892

Was putting up hay today. Had a good day and we topped out a stack about $30 \mathrm{ft}$. long for fear of rain. Brought a load of hay home and put in the barn. Splendid dry hay.

${ }^{47}$ W. J. Welch runs the Star Grocery in Iowa City. 


\section{Terrace Mound Farm}

Friday, July 8, 1892

Cut a piece of grass down this morning and tied the hay until the boys came and then we went to hauling. Put 4 load in to Frank Danner's barracks ${ }^{48}$ and brought one load home to put in the barn.

Saturday, July 9, 1892

Went down to cut hay this morning. The boys shelled some corn and came down and we loaded one load. Rain came up and we went to plowing corn.

Monday, July 11, 1892

It has been a fair day and very warm about 95 in the shade. Had some grass down over Sunday. Put it up today and cut some more. Got a long stack finished and started another one. Put 2 more loads in Frank Danner's barracks and brought 2 home.

\section{Wednesday, July 13, 1892}

This was a fair day. Did not make any hay today. Ground some feed and shelled a load of corn. Killed a calf and took load of hogs and two cows to [town] tonight.

Friday, July 15, 1892

Fair day, pretty high wind. I mowed this forenoon and we put hay in the barn, had a successful haul-in the hay. Mr. Thompson was over and got a piece of meat this morning.

Saturday, July 16, 1892

This has been a splendid hay day. Got in a good lot. Monday, July 18, 1892

Got in the hay left over from Saturday and before we got done it rained. I went to Iowa City. Sold a calf skin for 50 cts. Mowed this evening.

Saturday, July 23, 1892

Very warm. I took the butter to town and got home by noon. Boys took load of hay up to Mr. Furniss and we shelled a load of corn to soak for the pigs.

Tuesday, July 26, 1892

This was a good hay day. Got along first rate. Horses felt the heat very much.

${ }^{48}$ The "barracks" is likely a simple pole building that features open sides. 
Thursday, July 28, 1892

It threatened rain this morning. We went and finished the hay stacks before breakfast. After breakfast went and got the binder out and cut around the oats before dinner. After dinner it rained so we could not cut. Rained tonight.

Saturday, July 30, 1892

Had a good day cutting oats today. Edgar went over to help Frank Danner in his oats. Stair set up our oats.

Monday, August 1, 1892

This was a fine day for the 1st of August. We finished cutting oats today.

Saturday, August 6, 1892

We finished stacking our oats today. I took the butter in [to town] this evening.

Tuesday, August 9, 1892

Very warm today. Stair, Ma and I went to town today. The circus was in town.

Tuesday, August 16, 1892

Been quite warm today. I was working at making crates to take the pigs to State Fair [in Des Moines]. Boys were hauling out manure from the sheep shed.

Wednesday, August 17, 1892

Nice day. Pretty warm. Killed a calf this morning. I went to town this afternoon and took in calf skin. Got 40 cents for it. Monday, August 22, 1892

This is a fair day. Boys were hauling manure, I was trimming hedge on the south road. Got it all trimmed. Roads are very dusty.

Wednesday, August 24, 1892

Day was fine. We were fixing hogs for State Fair. Got in to city and loaded the pigs at depot at 11:00.

Thursday, August 25, 1892

Slept in the freight car among the hogs. Train was waylaid on all the sidings. Got away from Iowa City at 12 o'clock at night. Friday, August 26, 1892

Got to Des Moines at 12 o'clock [noon]. Got out to the fair 
ground between 2 and 3 . By night was very tired. Pigs would not eat much.

Saturday, August 27, 1892

Got up early and found a nice day coming. Got the pigs cleaned up and went out over the grounds.

Sunday, August 28, 1892

Was cloudy this morning. Had a nice day. Attended the hogs. Went up town after supper. Heard a lecture on "Columbus Discovered America." 49

Monday, August 29, 1892

Spent today on the State Fair ground. ${ }^{50}$ Washed up and attended the pigs and priced them. Sold a boar for $\$ 40$ to go to State Center, [Iowa].

Tuesday, August 30, 1892

Got up early and had a nice day. Sold several pigs. Met lots of folks from different parts.

Thursday, September 1, 1892

Just have two boars this morning and I hope to close them out. Sold both my boars this morning and I go up town for supper.

Friday, September 2, 1892

I felt rather bad this morning and had to give up my business. The boys became alarmed and sent for the doctor who came and said I had malaria and left medicine and his telephone No. Saturday, September 3, 1892

Was very sick all night. Felt better but weak this morning. Boys got a buggy and took me to the streetcar line. Then I went to RR Depot and came in on ten o'clock train.

Sunday, September 4, 1892

I laid around all day. Still feel very weak and beginning to

${ }^{49}$ While the Des Moines press failed to mention the Columbus speech, Americans, of course, were interested in the 400th anniversary of the Italian's voyage.

${ }^{50}$ Although the author has been at the Iowa State Fair since Friday, the formal opening of this annual agricultural extravaganza did not occur until 9:00 a.m. Monday. The Fair closed officially on Friday, September 2nd. 
want to eat. S. H. Thompson came over to see me. I feel very sore on my bowels.

\section{Monday, September 5, 1892}

This was a fine day. Air cool and bracing. Boys plowed and hauled manure and done chores. I went to town and took in my mail. Wrote and sent Pedigrees to parties that bought pigs off me at the state fair.

Tuesday, September 6, 1892

I went to town early this morning to get the tire set on the buggy wheel and get the colt shod. I got money out the express office from a Mr. Baker for pig $\$ 10$ and draft for $\$ 32.50$ from Victor, [Iowa] from Mr. Bohstedt.

Thursday, September 8, 1892

We have quite a rain this morning. Slacked up about 9 o'clock. $\mathrm{Ma}$ and I went to West Liberty to attend the fair. ${ }^{51}$

\section{Friday, September 9, 1892}

Rained a little early in the morning before we were up. We got up pretty early and went to the fair. Ma went shopping before I went to the fair ground. Had a nice day and we started home middle afternoon.

Tuesday, September 20, 1892

Was at home today and cut some weeds and pulled two pails of grapes and Edgar was plowing for wheat. It's most too dry to plow. Ma did a washing today.

Friday, September 23, 1892

We were threshing today. We had 709 bu. of oats. Got done at noon.

\section{Saturday, September 24, 1892}

Very warm today. Ma and Anna ${ }^{52}$ and I went to town and took Father with us. We ate dinner in Lentz's. ${ }^{53}$ I got a new suit of clothes for $\$ 18.00$ and overcoat for $\$ 10$. Edgar helped Frank Danner haul wood from the timber today.

\footnotetext{
${ }^{51}$ West Liberty, located only several miles from the Slemmons farm, hosts the popular Muscatine County Fair.

${ }^{52}$ Anna is the third Slemmons child, born February 19, 1872. She will marry Victor Morehead on September 12, 1893.

${ }^{53}$ The Peter Lentz restaurant is found at 19 Washington in Iowa City.
} 


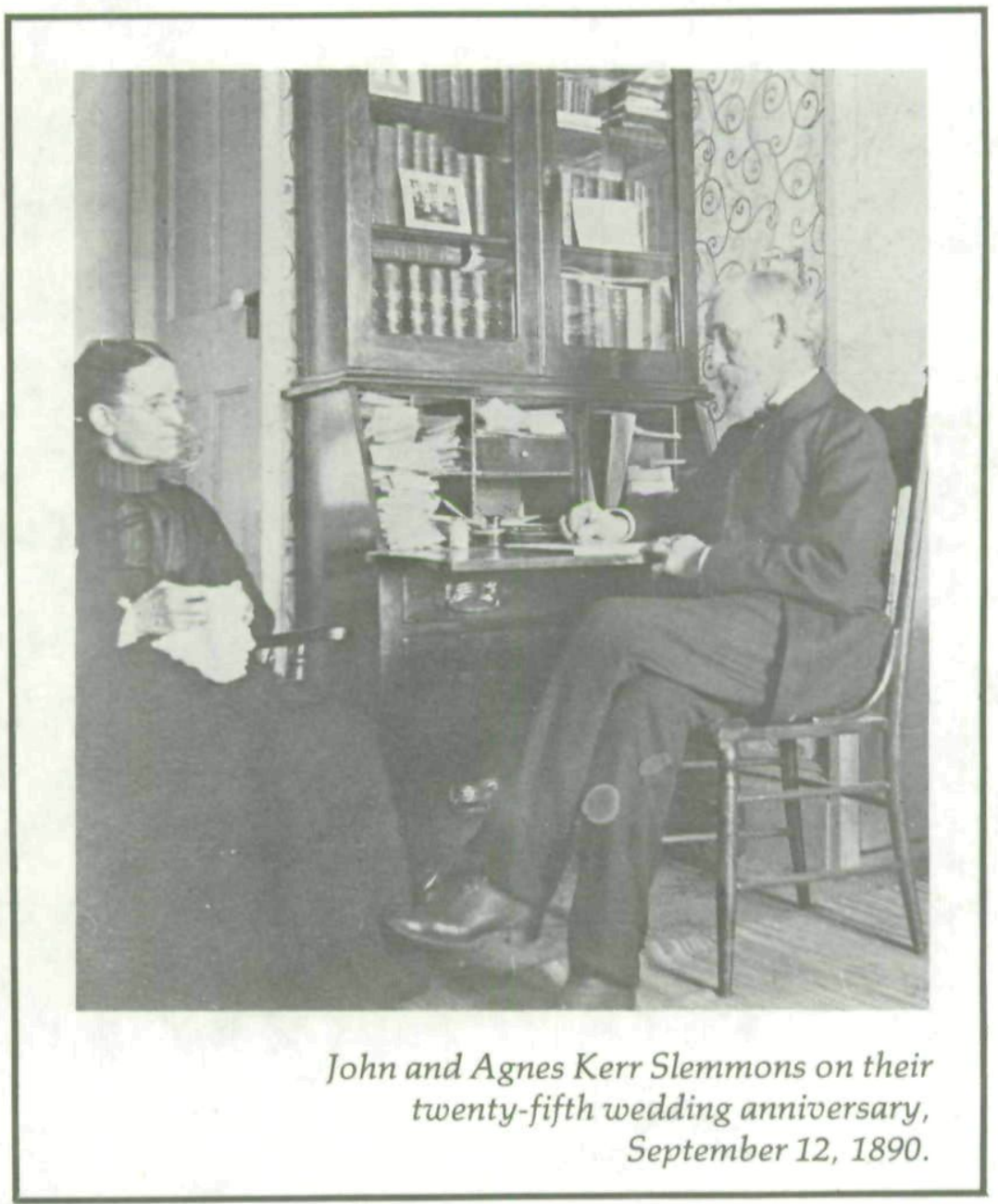

Friday, September 30, 1892

It was quite warm today. Father, $\mathrm{Mat}^{54}$ and I got what mail there was and got home by noon. Mat went for the seeder and began his sowing of fall wheat. Just got a good start this evening.

\section{Tuesday, October 11, 1892}

Was home all day. The weather is still dry and warm. We

${ }^{54}$ Mat is the author's half-brother, Matthew Slemmons, born at Cadiz, Ohio on June 17, 1850. He likewise farms in Johnson County. 


\section{The Annals of Iowa}

fenced in a hay stack and let the cattle in on a meadow. I wrote 5 letters.

Wednesday, October 12, 1892

Still dry and warm. I was raking up cobs and burning for the hogs. Edgar was doing chores. Victor Morehead came out and Anna and he went back to town in the single buggy.

Saturday, October 15, 1892

Anna and I went to town today. Roads were a little slippery for the horses. I got some lumber to put case around the big tank to put roof on. Also got $\$ 15$ worth lumber and nails.

Tuesday, October 18, 1892

Clear and cool this morning. Edgar and I worked at the tank cover all day.

Saturday, October 22, 1892

Cool and fair. Sold a boar pig to Mr. DeLancy of Washington County. Went to town in the afternoon and took in the butter. Thursday, October 27, 1892

I went to West Liberty to attend [a] hog sale. The day was fine and there was not a very big attendance. I came home with $\mathrm{Mr}$. Sheridan of Iowa County.

Friday, October 28, 1892

I did chores while Edgar husked the corn. Went to church tonight.

Sunday, October 30, 1892

Nice cool day. Had a good congregation out to church. Had communion. There [were] 6 children baptized. Margaret \& Frank were over this evening.

Tuesday, November 1, 1892

Cold and wet today. We were up pretty late in the morning. Edgar gathered a load of corn this afternoon and I worked at the roof on the tank.

Saturday, November 5, 1892

Both the boys went to the cornfield this morning to gather corn and I did chores. Stair and I shelled and ground a load of corn for cowfeed while Ed husked corn.

Monday, November 7, 1892

Cold and stormy. I took our sheep, 56 head, to ship to Chicago. 


\section{Terrace Mound Farm}

Tuesday, November 8, 1892

Clear and cool. I did chores and helped Edgar gather a load of corn in the morning and then went to the Election in the afternoon. Voted the strait [sic] Republican ticket. Went to preaching at Scott [Church] at night.

Friday, November 11, 1892

Took the early train for Des Moines to attend a cattle sale held by Geo. Lyle of Monroe, Iowa. Jno. Waldron met me at the depot. Left for home at four [p.m.] and got to Iowa City about nine.

Thursday, November 17, 1892

This was one of the worst stormy days of the season. Commenced sprinkling rain in the morning with the wind in N.W. and turned to snow and blew a gale as the day advanced and the snow piled up in heaps and weighted down the trees.

Saturday, November 19, 1892

Pretty fair day. Thawed a little during the day and froze again at night. Edgar \& Stair husked a load of corn and we shelled it for feed.

Monday, November 21, 1892

Day was fine. We did some grinding of feed for the stock. Father was up and selected a boar pig. I bred a sow pig today by the name of Nips June-to the boar Geo. Washington.

Thursday, November 24, 1892

We all went to Grandpa's today for our Thanksgiving dinner. Tuesday, November 29, 1892

Edgar and I did the chores and banked up the lower tank. Hauled some straw and fixed up the hog pens so as to make the hogs more comfortable.

Thursday, December 1, 1892

Damp and foggy this morning. The dehorning machine came before we got chores done. Dehorned 28 head and altered 5 calves. Ground some feed today. Tried to breed a cow.

Friday, December 9, 1892

I went to Iowa City today. Got a shoe put on the gray mare. Delivered the butter. Got some subscribers for the Gazette and bought a carpet and got a pig at express office. 


\section{The Annals of Iowa}

Thursday, December 15, 1892

Was home doing chores today. Was a fine winter day. Helped put down carpet and put away pork. Ground and shelled a load of corn. Jim Hedges brought up a sow and bred to Prince.

Saturday, December 17, 1892

Boys did chores and husked corn. I took a boar pig to town [and] got \$14 for him. Took several subscriptions for Breeder's Gazette, sent in 11 subscribers to the office.

Tuesday, December 20, 1892

It was 11 degrees below zero this morning. The coldest day of the season. Edgar went to haul hay. Mike Paulus was down looking at the bull calf.

Wednesday, December 21, 1892

I went to Iowa City today. It was some warmer than yesterday. Edgar did the chores. I got a load of 22 bushel of coal home with me.

Friday, December 23, 1892

Went to the city today with the sled and got a sack of flour and got a few subscribers for the Breeder's Gazette. Was getting ready for Christmastide at our house.

Friday, December 30, 1892

The day was mild, pretty near a thaw. The boys hauled two loads of hay from the Danner place, finished hauling our share. I ground a load of corn in the afternoon and went to Scott church.

Saturday, December 31, 1892

I went to Iowa City today. Delivered the butter and got out to Ed Greevers for dinner. All the family was there. 
Copyright of Annals of Iowa is the property of State of Iowa, by \& through the State Historical Society of Iowa and its content may not be copied or emailed to multiple sites or posted to a listserv without the copyright holder's express written permission. However, users may print, download, or email articles for individual use. 